\title{
Adana merkez ve ilçeleri için çiftlik hayvanları kaynaklı atık ve kirlilik yükü potansiyeli
}

\author{
The potential of waste and pollution load from livestock for Adana center and \\ districts
}

\author{
Müge ERKAN CAN \\ Çukurova Üniversitesi, Ziraat Fakültesi, Tarımsal Yapılar ve Sulama Bölümü, 01330, Adana \\ Sorumlu yazar (Corresponding author): M. Erkan Can, e-posta (e-mail): merkan@cu.edu.tr
}

\section{MAKALE BİLGISİ}

Alınış tarihi 01 Ocak 2021

Düzeltilme tarihi 06 Nisan 2021

Kabul tarihi 12 Nisan 2021

\section{Anahtar Kelimeler:}

Ahır gübresi

Kümes gübresi

Hayvansal kirlilik yükü

Adana

\begin{abstract}
ÖZ
Bașlıca kirlilik kaynakları olarak bünyesinde, yoğun miktarda hayvansal gübre ve ișletme içi atık bulunan hayvancılık sektörü atıklarını belirli bir atık yönetimi olmadan kullandığında bu durum doğal çevreye telafisi imkânsız olan zararlar verebilecektir. Bu zararların izlenmesi amacıyla, çalışma alanı için büyükbaş hayvanlardan ve tavuklardan elde edilebilecek hayvansal atık potansiyelini somut ve güncel verilerle belirlemek ve sıklıkla ihmal edilmiş olan hayvan gübresinin kirlilik risklerine dikkat çekmek hedeflenmiștir. Adana ili ve ilçelerindeki büyükbaş hayvan ve kümes hayvanları (etlik piliç ve yumurta tavuğu) sayıları belirlendikten sonra bu sayılara ait toplam gübre miktarları 2018 ve 2019 yıllarında sırası ile; büyükbaş hayvanlar için 2899541.9 ton $\mathrm{yll}^{-1}$ ve 2891551.4 ton $\mathrm{yll}^{-1}$ kümes hayvanları için 481670.6 ton $\mathrm{yll}^{-1}$ ve 442646.0 ton $\mathrm{yll}^{-1}$ olarak hesaplanmıştır.
\end{abstract}

\section{ARTICLE INFO}

Received 01 January 2021

Received in revised form 06 April 2021

Accepted 12 April 2021

\section{Keywords:}

Barn manure

Poultry manure

Animal pollution load

Adana

\begin{abstract}
When the livestock sector, which includes a large amount of animal manure and waste as the main source of pollution, uses its waste without a specific waste management, this can cause irreparable damage to the natural environment. In order to monitor these damages, it is aimed to determine the potential of farm animal waste that can be obtained from cattle and chickens for the study area with concrete and up-to-date data and to draw attention to the pollution risks of livestock manure which is often neglected. After determining the number of cattle and poultry (broiler and laying hen) for Adana province and its districts, the total manure amounts for 2018 and 2019 years were calculated respectively as 2899541.9 tons year $^{-1}, 2891551.4$ tons year ${ }^{-1}$ and for poultry 481670.6 tons year $^{-1}, 442646.0$ tons year ${ }^{-1}$.
\end{abstract}

\section{Giriş}

Hayvancılık sektörü ve teknolojisi artan nüfus ile paralel olarak sürekli gelişim ve değişim halinde olan bir alandır. Hayvan atıklarından kaynaklanan ve dağınık kirlilik olarak değerlendirilen çevre sorunları kimi endüstriyel atıklar kadar zararlı olabilmektedir. Özellikle yüzey sularının alıcı ortamlara drenajı, tarımdan dönen sular ve hayvan atıklarının sürekli depolama alanı olarak kullanıldığı araziler ve depo sızıntı suları su kirliliğinin başlıca kaynakları olarak ortaya çıkmaktadır. Dolayısıyla yapılan çalışmaların güncelliğini koruması, mevcut durumun tespit edilmesi ve geri dönüşümsüz zararların önlenebilmesi için gereken önlemlerin en kısa sürede alınması hayvancılık ve hayvansal atıkların yönetimi ve çevre için hayati önem arz etmektedir.
Hayvansal gübreler, toprak için değerli bir besin madde sağlayıcı ve toprak şartlarını düzenleyicidir. Uygun bir şekilde olgunlaştırılarak kullanılan hayvansal gübreler, ticari gübrelere göre daha iyi, çevreye daha az zararlı ve ekonomik bir bitki besin maddesi sağlayabilir. Hayvan gübreleri organik madde içeriği bakımından zengin olan bir gübredir ve bu sayede toprağın su tutma kapasitesini artırdığ 1 gibi toprağa önemli ölçüde azot $(\mathrm{N})$, fosfor $(\mathrm{P})$, potasyum $(\mathrm{K})$ ve sülfür $(\mathrm{S})$ gibi bitki besin elementlerini sağlar. Çiftlik gübresinin besin madde içeriği; hayvanın cinsi, yaşı, yedirilen yemin miktarı ve yemin besin değeri, hayvanların yaptığı iş, kullanılan yataklığın cinsi ve miktarı, gübredeki katı dışkı ve idrar oranı, ahırın durumu ve saklama tekniğine bağlı olarak önemli değişkenlikler gösterebilmektedir (Kaçar ve Katkat 2009). 
Toprak özellikleri ve bitki gelişimine pek çok katkısı olan böyle bir kaynaktan günümüzde maalesef çok yetersiz düzeyde yararlanılmaktadır. Hayvan gübrelerinden beklenen faydanın sağlanması için kompost yapılması önemli bir husustur. Ancak kompost yapılmasındaki bilgi ve olanak eksikliği hayvan gübrelerinin iyi bir organik gübreye dönüştürülmesini ciddi biçimde zorlaştırmaktadır. Bu sırada başta azot olmak üzere önemli bitki besin maddesi kayıları olmakta aynı zamanda etrafa yayılan kötü koku ve sinek sayısındaki artış çevresel problemlere neden olmaktadır (Kütük ve Çayc1 2010). Ülkemizde gerek iş kolu olarak gerekse yaptırım ve pratik uygulamalar bakımından hayvansal atıklar konusu henüz yeterli yayılma ve ilgi düzeyine gelememiştir. Türkiye'de, çiftlik gübre üretimi ile alakalı olarak kesin değerler bulunmamaktadır. Özellikle koyun ve besi sığırı işletmelerinde hayvanların yılın belirli zamanlarında merada bulunmaları nedeniyle bu dönemlerde açığa çıkan gübrenin biriktirilmesi mümkün olamamaktadır. Hayvanların barınak içerisinde bulundukları dönem ve hayvan varlığı göz önüne alındığında, yılda yaklaşık 82 milyon ton gübre açığa çıkmaktadır. Bunun büyük bir kısmı (\%81) büyükbaş hayvan ve tavuk yetiştiriciliği işletmelerinden elde edilmektedir. Bu gübrenin \%75'inin tezek haline getirilerek kırsal alanlarda yakıt olarak kullanıldığı dikkate alınırsa ülkemizde, elde edilen gübrenin ancak $\% 25$ kadarlık kısmı kompost üretimde değerlendirilmektedir (Olgun ve Polat 2005).

Gübre üretimi ve kullanımı için çeşitliliğinin artırılmasına özel bir önemin gösterilmesi gereklidir. Özellikle kompost gübrelere olan talep artışı bu konuda çalışmaların yoğunlaştırılmasını gerekli kılmaktadır (Kaplan 1999).

Bu konudaki çeşitli veriler incelendiğinde, Türkiye'de çıkan yıllık kümes atığı miktarının yaklaşık 10 milyon tonu bulduğu söylenebilir. Atık olarak nitelendiğinde ciddi çevre sorunlarına sebep olabilecek bu miktar, ham madde olarak değerlendirilebilirse değerli bir kaynak olabilecek potansiyeldir. Tavuk gübresini hammadde olarak kullanıp işlenmiş ürün haline getiren pek çok teknik ve teknoloji mevcuttur. Bu yöntemler içinde atıkların pellet haline getirildikten sonra organik gübre olarak kullanımı en yaygın değerlendirme şekillerinden biridir. Türkiye topraklarının yetersiz organik madde içeriği ve kullanılan ticari gübre miktarları bir arada düşünüldüğünde tavuk atıklarının organik gübre kaynağı olarak kullanımı pratik bir çözüm olarak görülebilir.

$\mathrm{Bu}$ çalıșmanın amacı; yöredeki büyükbaş hayvancılık ve kümes işletmelerinde oluşan atıkların potansiyel miktarını ve kirletici yüklerini (toplam azot $\left(\sum \mathrm{N}\right)$, toplam fosfor $\left(\sum \mathrm{P}\right)$ ) somut ve güncel verilerle belirlemek ve sıklıkla ihmal edilmiş olan hayvan gübresinin kirlilik risklerine dikkat çekmektir.

\section{Materyal ve Yöntem}

Hayvansal atık miktarlarının belirlenebilmesi amacıyla öncelikle Adana ili ve ilçeleri için 2018, 2019 yıllarına ait büyükbaş ve kümes hayvanı sayıları devlet kurumlarına ait veri tabanlarından her hayvan grubu için ayrı ayrı derlenerek materyal olarak kullanılmıştır (TUIK 2018 ve TUIK 2019). Adana ili ve ilçelerine ait detaylı hayvan sayıları Çizelge 1'de verilmiştir (TUIK 2018 ve TUİK 2019). Elde edilen 2018 y11 ve 2019 yılı hayvan sayıları verilerine göre, Adana'da toplamda 2018 yılı için 265430 adet büyükbaş ve 7236248 adet tavuk (etlik piliç ve yumurta tavuğu); 2019 yılı için ise 259684 adet büyükbaş ve 6556620 adet tavuk (etlik piliç ve yumurta tavuğu) bulunmaktadır.

Tarım ve hayvancılık yönünden Türkiye'nin en önemli şehirleri arasında yer alan ve şehir merkezinin denizden yüksekliği 23 m olan Adana ilinin; Seyhan, Sarıçam, Çukurova, Yüreğir, Aladağ, Ceyhan, Feke, İmamoğlu, Karaisalı, Karataş, Kozan, Pozantı, Saimbeyli, Tufanbeyli ve Yumurtalık olmak üzere, sosyo ekonomik yapı, sanayi ve yapılan tarım açısından birbirinden bazı farklılıklar gösteren 15 ilçesi bulunmaktadır. Yörede ortalama oransal nem \%66 olmakla beraber, yaz aylarında bazı günler \%90'ın üzerine çıkar. Aladağ, Feke, Pozant1, Saimbeyli, Tufanbeyli ilçeleri dağlık ve yüksek yayla karakterindeki geçit bölgeleri olup, ova kesiminden farklı iklim değerlerine sahiptir. Adana alt bölgesi yıllık ortalama rüzgâr

Çizelge 1. Adana ili ve ilçelerinin 2018 ve 2019 yılları için hayvan sayıları

Table 1. Animal numbers of Adana province and districts for years of 2018 and 2019

\begin{tabular}{|c|c|c|c|c|c|c|c|c|c|c|}
\hline \multirow[t]{2}{*}{ İlçe } & $\begin{array}{c}\text { Et } \\
\text { Tavuğu }\end{array}$ & $\begin{array}{c}\text { Yumurta } \\
\text { Tavuğu }\end{array}$ & $\begin{array}{c}\text { Süit } \\
\text { Sığırı }\end{array}$ & $\begin{array}{l}\text { Besi } \\
\text { Sığı̆ı }\end{array}$ & $\begin{array}{c}\text { Genç Yavru } \\
\text { (Buzağı vd) }\end{array}$ & $\begin{array}{c}\text { Et } \\
\text { Tavuğu }\end{array}$ & $\begin{array}{c}\text { Yumurta } \\
\text { Tavuğu }\end{array}$ & $\begin{array}{c}\text { Süit } \\
\text { Sığırı }\end{array}$ & $\begin{array}{c}\text { Besi } \\
\text { Sığı̆ıI }\end{array}$ & $\begin{array}{l}\text { Genç Yavru } \\
\text { (Buzağı vd) }\end{array}$ \\
\hline & \multicolumn{5}{|c|}{2018 yılı } & \multicolumn{5}{|c|}{2019 yılı } \\
\hline Aladağ & 295000 & 3000 & 2867 & 655 & 1642 & 295000 & 0 & 2565 & 607 & 1585 \\
\hline Ceyhan & 1250000 & 312000 & 16515 & 3703 & 6242 & 1189421 & 35550 & 16554 & 3769 & 6330 \\
\hline Feke & 0 & 17830 & 13513 & 2533 & 3037 & 0 & 17840 & 16388 & 3992 & 4369 \\
\hline Karaisalı & 498650 & 7227 & 9625 & 2071 & 5506 & 504749 & 8250 & 9715 & 2107 & 5650 \\
\hline Karataş & 0 & 5325 & 7901 & 3127 & 4112 & 0 & 4325 & 8567 & 2943 & 2817 \\
\hline Kozan & 45000 & 40000 & 17379 & 1645 & 8422 & 45000 & 38000 & 15237 & 1933 & 7909 \\
\hline Pozant1 & 65000 & 1690 & 879 & 189 & 441 & 65000 & 600 & 1161 & 219 & 532 \\
\hline Saimbeyli & 0 & 17200 & 4421 & 487 & 1611 & 0 & 16900 & 5428 & 549 & 2611 \\
\hline Sarıçam & 761000 & 230000 & 28699 & 5071 & 14461 & 645000 & 120000 & 19947 & 2690 & 7453 \\
\hline Seyhan & 1564690 & 172140 & 6435 & 24197 & 2669 & 1564715 & 202170 & 9276 & 29889 & 2941 \\
\hline Tufanbeyli & 0 & 14500 & 8094 & 1262 & 4755 & 0 & 14650 & 8689 & 1593 & 4636 \\
\hline Yumurtalık & 0 & 15000 & 4955 & 847 & 2513 & 0 & 14950 & 4796 & 545 & 1895 \\
\hline Yüreğir & 1375000 & 3650 & 15041 & 9054 & 7045 & 1251250 & 4100 & 13549 & 7478 & 6137 \\
\hline Çukurova & 320000 & 2500 & 2645 & 382 & 1240 & 320000 & 2750 & 2700 & 520 & 1430 \\
\hline İmamoğlu & 141214 & 78632 & 4387 & 467 & 2688 & 126000 & 70400 & 6109 & 655 & 3219 \\
\hline Toplam (Adet) & 6315554 & 920694 & 143356 & 55690 & 66384 & 6006135 & 550485 & 140681 & 59489 & 59514 \\
\hline
\end{tabular}


hızı $2.1 \mathrm{~m} \mathrm{~s}^{-1}$ güneybat1-kuzeybatı yönünden esmektedir. En yüksek rüzgâr hızı $25 \mathrm{~m} \mathrm{~s}^{-1}$ 'dir. Adana bölgesi verilerine göre y1lda ortalama 118-281 gün güneşli geçmektedir. Günlük güneşlenme süresi yaklaşık olarak 7 saat 24 dakikadır (Adana Tarım Master Planı 2005). Yıllık ortalama yağış miktarı 450-736 mm arasında değişmekte olup, uzun yıllar alt bölge yağış ortalaması $676.63 \mathrm{~mm}$ 'dir. Adana alt bölgesi ova kesiminde çok ender olarak görülen kar yağışı, alçak kesimlerde olmamakta, ancak orta yayla kesimleri ile yüksek dağlik olan kesimlerde uzun süre kalabilmektedir (Erkan Can 2011). Adana ilinde 342959 hektar olan alüviyal topraklar Kozan, Ceyhan ve Yüreğir ovalarında bulunmaktadır (Adana Tarım Master Planı 2005).

Hayvanların günlük gübre üretim miktarları hesaplanırken literatür bilgileri derlenerek belirlenen kabuller kullanılmış ve süt sığırı için $43 \mathrm{~kg}$ hayvan gün ${ }^{-1}$, besi sı̆̆ırı için 29 $\mathrm{kg}$ hayvan gün ${ }^{-1}$, genç yavru sığırlar için $2.48 \mathrm{~kg}$ hayvan gün ${ }^{-1}$, et tavuğu için $0.19 \mathrm{~kg}$ hayvan gün ${ }^{-1}$ ve yumurta tavuğu için 0.13 $\mathrm{kg}$ hayvan gün-1 değerleri işleme alınmıştır. Bulunan günlük gübre üretim miktarları yıllık olarak hesaplanmış ve ilgili çizelgelerde verilmiştir (Ayhan 2015, Tinmaz Köse 2017, Dağtekin ve ark. 2019, Yağlı ve Koç 2019, Salihoğlu ve ark. 2019, Polat Bulut ve Topal Canbaz 2019).

Hayvancılıktan kaynaklanan yayılı yükler; TÜİK tarafından yıllık olarak üç kategoride büyükbaş, küçükbaş, kümes hayvanı olarak sınıflandırılmıştır. Çalışmamız kapsamında küçükbaş hayvanlar olmadığından bu kategori hesaplamalara dâhil edilmemiştir. Hayvancılık kaynaklı yayılı yük miktarları hesaplanırken Adana ili hayvan sayılarının; literatürden elde edilen ve hayvan türüne göre seçilen kirletici yükü katsayıları ile çarpılması yöntemi kullanılmıştır. Yayılı kirlilik yükü hesaplamasında hayvansal faaliyetlerden kaynaklanan kirliliğin alıcı ortama ulaşma katsayısı azot için $\% 15$, fosfor için $\% 5$ olarak; hayvan ağırlıkları ise; büyükbaş hayvan için $500 \mathrm{~kg}$ ve kümes hayvanı için $2 \mathrm{~kg}$ olarak kabul edilmiş ve bu kabullere göre hesaplamalar yapılmıştır. Hayvancılıktan kaynaklanan olası yayılı yük hesaplamaları için literatürden seçilen katsayılar hayvan türüne göre Çizelge 2'de verilmiştir (Animal Waste 2001, Andreadakis ve ark. 2007, Öztürk 2008, Biçer 2011, Orman ve Su İşleri Bakanlığı 2013, Yetiş ve ark. 2018a). Kirlilik yükleri ve ilgili diğer veriler hesaplanırken literatürden faydalanılarak uyarlanan aşağıdaki eşitlikler kullanılmıştır.

$$
\text { Eşitlik 1: YGÜ= }\left(\mathrm{K}^{*} \mathrm{HS}\right) 365
$$

Eşitlikte; YGÜ: Yıllık yaş gübre üretimi (ton hayvan $\mathrm{y}^{1^{-1}}{ }^{1}$ ), $\mathrm{K}$ : Hayvan cinsine göre günlük gübre üretim miktarı kabulleri (kg hayvan gün ${ }^{-1}$ ) ve HS: Hayvan sayısıdır.

\section{Eşitlik 2: KY= HS*YYK}

Eşitlikte; KY: Hayvancılıktan kaynaklanan kirlilik yükleri (kg hayvan $\mathrm{yl}^{-1}$ ) ve YYK: $\sum \mathrm{N}$ ve $\sum \mathrm{P}$ için seçilen yayılı yük katsayıları ( $\mathrm{kg}$ hayvan $\left.\mathrm{yl}^{-1}\right)^{\text {'d }}$ ır.

\section{Eşitlik 3: AOUM=KY*AOUY}

Eşitlikte; AOUM: Alıcı ortama ulaşan kirlilik miktarı ve AOUY: Kirliliğin alıcı ortama ulaşma yüzdesi (\%)'dir.
Çizelge 2. Hayvancılık faaliyetlerinden kaynaklanan yayılı yük katsayıları

Table 2. Distributed load coefficients resulting from livestock activities

\begin{tabular}{|c|c|c|c|c|}
\hline $\begin{array}{c}\text { Hayvan } \\
\text { Türü } \\
\end{array}$ & $\underset{\left.\text { (kg hayvan yil }^{-1}\right)}{\sum N}$ & $\begin{array}{c}\text { Alıci } \\
\text { Ortama } \\
\text { Ulaşan } \\
\sum \mathbf{N}(\%) \\
\end{array}$ & $\underset{\left.\text { (kg hayvan yll }^{-1}\right)}{\sum P}$ & $\begin{array}{c}\text { Alıci } \\
\text { Ortama } \\
\text { Ulaşan } \\
\sum \mathbf{P}(\%) \\
\end{array}$ \\
\hline $\begin{array}{l}\text { Büyükbaş } \\
\text { Hayvan }\end{array}$ & 8.2 & 0.15 & 0.91 & 0.05 \\
\hline $\begin{array}{l}\text { Kümes } \\
\text { Hayvanı }\end{array}$ & 0.06 & 0.15 & 0.008 & 0.05 \\
\hline
\end{tabular}

\section{Bulgular ve Tartışma}

Çizelgelerde verilen hayvan sayıları ve yöntem kısmında bildirilen kabuller kullanılarak ildeki hayvansal gübre miktarları hesaplanmıştır. Hesaplanan hayvansal gübre miktarlarına ait değerler büyükbaş hayvancıllk için Çizelge 3'de, kümes hayvanları için Çizelge 4'de verilmiştir.

Adana genelinde 2018 yılında, büyükbaş hayvanlardan toplamda 2899541.9 ton $\mathrm{y}^{1}{ }^{-1}, 2019$ y1linda 2891551.4 ton $\mathrm{y}^{-1}{ }^{-1}$; etlik piliçlerden ve yumurta tavuklarından ise 2018 yılında 481670.6 ton $\mathrm{y}^{1}{ }^{-1}, 2019$ yılinda 442646 ton $\mathrm{y}^{1}{ }^{-1}$ gübre üretilmiştir.

Kurnuç Seyhan ve Badem (2018)'in Erzincan ilinde yürüttükleri çalışmada hayvan sayıları ve türlerine bağlı olarak oluşan atık miktarları; 352187 ton atık yıl ${ }^{-1}$ ile büyükbaş hayvanlar ve 40078 ton atık y1 ${ }^{-1}$ kanatlı hayvanlar şeklinde sıralanmaktadır. İlçe bazlı hayvan atık dağılımı incelendiğinde ise toplamda en fazla atığın 174860 ton atık yıl ${ }^{-1}$ ile Merkez ilçede gerçekleştiği hesaplanmıştır. Yağlı ve Koç (2019)'un çalışmasında, Adana genelinde 2018 yılı için 2919221.645 ton $\mathrm{y}_{1}{ }^{-1}$ büyükbaş, 653082.875 ton $\mathrm{y}^{-1}{ }^{-1}$ küçükbaş ve 118588.952 ton $\mathrm{y}^{1} \mathrm{l}^{-1}$ ise kanatlı hayvan gübresinin oluştuğu vurgulanmaktadır. Dağtekin ve ark. (2019)'nın Adana ve Mersin'de bulunan etlik piliç (broiler) işletmelerinde oluşan gübrelerin biyogaz enerji potansiyelini belirlemek amaciyla yaptıkları çalışmada, Adana ili yıllık toplam yaş gübre miktarını 458345.54 ton olarak hesaplamışlardır. Hesaplanan bu gübrenin yaklaşık \%25'i Ceyhan'da, \%21'i Yüreğir'de, \%20'si Seyhan ilçelerinde bulunmaktadır. Yelmen ve ark. (2020), Mersin ilinde yürüttükleri araştırmalarında büyükbaş hayvan yaş gübre miktarını 415821.6 ton $\mathrm{y}^{-1}{ }^{-1}$ ve kümes hayvanı yaş gübre miktarını 603095.5 ton yı1 ${ }^{-1}$ olarak hesaplamışlardır.

Özetlenen literatür içerisinde Adana ilinde yürütülen araştırmaların seçili verileri çalışma bulgularımızla uyumlu bulunmuştur. Farklı yöredeki araştırmalarda ise sonuçların farklılaştı̆̆ bakımından oranlama yapıldığı takdirde paralellik gösterdiği söylenebilir. Çalışmada elde edilen hayvansal gübre miktarına ilişkin değerler gübrelerin toplanabilir kısmı için kabul edilen oranlarda hesaplandığından potansiyel miktarlar olup asıl gübre miktarının daha fazla boyutta olacağı tahmin edilebilir. Hayvancılıktan elde edilen gübrelerin toplanabilirlik olasılıkları atığın barınaktan alınıp biriktirilme şekliyle, atıkların depolanma şartlarıyla, hayvanların barınakta kalma süreleriyle ve işletmenin gübre yönetimi imkânlarıyla doğru orantılıdır. Bunun yanı sıra otlatılan hayvanların gübreleri otlatıldıkları arazilerde kalacağından gübre üretim miktarlarında hesaba katılamayacaktır.

Hayvancılık işletmelerinden elde edilen gübre ve atıkların kirletici etkisinin il ve ilçeler bazındaki durumunu ortaya koyabilmek ve ne kadar ciddi miktarlara ulaştığını görebilmek için $\sum \mathrm{N}$ ve $\sum \mathrm{P}$ yükü miktarları hesaplanmıştır. Hesaplanan 
değerlere ilişkin sonuçlar 2018 yılı için Çizelge 5'de; 2019 yılı için ise Çizelge 6'da verilmiştir.

Biçer (2011)'in çalışmasında, Burdur alt havzaları bazında yayılı kirlilik kaynaklarından oluşan $\sum \mathrm{N}$ ve $\sum \mathrm{P}$ yüklerinin aylık tahminine ilişkin sonuçlar verilmiştir. Burdur Gölü alt Havzası'nda hayvancıllk faaliyetlerinden kaynaklanan $\sum \mathrm{N}$ miktarı 611 ton $\mathrm{y}_{1}{ }^{-1}(\% 50), \sum \mathrm{P}$ miktarı ise 93 ton $\mathrm{y}^{1}{ }^{-1}(\% 53)$ olarak hesaplanmıştır. Bu rakamlar dağılımdaki en yüksek oranlar olarak bildirilmiştir. Aybek ve ark. (2015)'nın Kahramanmaraş ilinde yürüttükleri araştırma kapsamında 2014 y1lı hayvan sayısı verilerine göre, il genelinde y1llık toplam kullanılabilir katı gübre miktarı yaklaşık 2494361 ton olarak hesaplanmıştır. $\mathrm{Bu}$ miktarın büyükbaş ve kanatlı hayvanlara göre yaklaşık değerleri sırasıyla 2006928 ton ve 36810 tondur. Yetiș ve ark. (2018b), yayılı kirlilik kaynaklarından olan hayvansal atıkların uygun olmayan şartlarda biriktirildiğinde oluşan sızıntı sularının, yerüstü ve yeraltı sularını kirleterek kalitesini bozması ve kullanılamaz duruma getirmesi konusu üzerinde yaptıkları çalışmada, üç kategoride (büyükbaş, küçükbaş ve kümes hayvanı) hayvan sayılarını kullanarak yıllık yayılı $\sum \mathrm{N}$ ve $\sum \mathrm{P}$ yüklerini hesaplamışlardır. Muş ili genelinde $\sum \mathrm{N}$ yükü 543412 ton $\mathrm{yll}^{-1}$ ve $\sum \mathrm{P}$ yükü 16918 ton y11 ${ }^{-1}$ olarak bulunmuştur. Bunun yanı sıra, bu konudaki çalışmalarda önem arz eden süreklilik hususuna da değinilerek detaylı periyodik izleme çalışmaları yapılması gerekliliği vurgulanmıştır. Yetiş ve ark. (2018a)'nın çalışmasında, Bitlis il genelinde çiftlik hayvanlarının gübrelerinden kaynaklanan $\sum \mathrm{N}$ yükü 180084 ton $\mathrm{y}_{1}{ }^{-1}$ ve $\sum \mathrm{P} 4854$ ton $\mathrm{y}^{-1}{ }^{-1}$ olarak hesaplanmıştır. Derin ve ark. (2019)'nın yürüttükleri çalışmada, Mardin il genelinde hayvan gübresi kaynakl1 $\sum \mathrm{N}$ yükü 270626 ton $\mathrm{y}^{-1}{ }^{-1}$ ve $\sum \mathrm{P} 7.89$ ton $\mathrm{y}^{-1}{ }^{-1}$ olarak hesaplanmıştır.

Çizelge 3. Büyükbaş hayvancılık için gübre üretim miktarları

Table 3. Manure production amounts for cattle breeding

\begin{tabular}{|c|c|c|c|c|c|c|c|}
\hline \multirow{3}{*}{ İlçe } & \multirow{3}{*}{$\begin{array}{l}\text { Toplam } \\
\text { Hayvan }\end{array}$} & \multicolumn{3}{|c|}{ Yıllık Gübre Üretimi (ton yıl' ${ }^{-1}$ ) } & \multicolumn{3}{|c|}{ İlçelere Göre Dağılım Oranları (\%) } \\
\hline & & Süt Sığırı & Besi Sığırı & Genç Yavru (Buzağı vd) & Süt Sığırı & Besi Sığırı & Genç Yavru (Buzağı vd) \\
\hline & & \multicolumn{6}{|c|}{2018 yılı } \\
\hline Aladağ & 5164 & 44997.6 & 6933.2 & 1486.3 & 2.00 & 1.18 & 2.47 \\
\hline Ceyhan & 26460 & 259202.9 & 39196.3 & 5650.3 & 11.52 & 6.65 & 9.40 \\
\hline Feke & 19083 & 212086.5 & 26811.8 & 2749.1 & 9.43 & 4.55 & 4.57 \\
\hline Karaisalı & 17202 & 151064.4 & 21921.5 & 4984.0 & 6.71 & 3.72 & 8.29 \\
\hline Karataş & 15140 & 124006.2 & 33099.3 & 3722.2 & 5.51 & 5.62 & 6.19 \\
\hline Kozan & 27446 & 272763.4 & 17412.3 & 7623.6 & 12.12 & 2.95 & 12.69 \\
\hline Pozantı & 1509 & 13795.9 & 2000.6 & 399.2 & 0.61 & 0.34 & 0.66 \\
\hline Saimbeyli & 6519 & 69387.6 & 5154.9 & 1458.3 & 3.08 & 0.87 & 2.43 \\
\hline Sarıçam & 48231 & 450430.8 & 53676.5 & 13090.1 & 20.02 & 9.11 & 21.78 \\
\hline Seyhan & 33301 & 100997.3 & 256125.2 & 2416.0 & 4.49 & 43.45 & 4.02 \\
\hline Tufanbeyli & 14111 & 127035.3 & 13358.3 & 4304.2 & 5.65 & 2.27 & 7.16 \\
\hline Yumurtalık & 8315 & 77768.7 & 8965.5 & 2274.8 & 3.46 & 1.52 & 3.79 \\
\hline Yüreğir & 31140 & 236068.5 & 95836.6 & 6377.1 & 10.49 & 16.26 & 10.61 \\
\hline Çukurova & 4267 & 41513.3 & 4043.5 & 1122.4 & 1.85 & 0.69 & 1.87 \\
\hline İmamoğlu & 7542 & 68854.0 & 4943.2 & 2433.2 & 3.06 & 0.84 & 4.05 \\
\hline Toplam & 265430 & 2.249 .972 .4 & 589.478 .7 & 60.090 .8 & 100.00 & 100.00 & 100.00 \\
\hline \multirow{3}{*}{ İlçe } & \multirow{3}{*}{$\begin{array}{l}\text { Toplam } \\
\text { Hayvan }\end{array}$} & \multicolumn{3}{|c|}{$\begin{array}{l}\text { Yıllık Gübre Üretimi (ton yıl } \\
\left.{ }^{-1}\right)\end{array}$} & \multicolumn{3}{|c|}{ İlçelere Göre Dağılım Oranları (\%) } \\
\hline & & Süt Sığırı & Besi Sığırı & Genç Yavru (Buzağı vd) & Süt Sığırı & Besi Sığırı & Genç Yavru (Buzağı vd) \\
\hline & & \multicolumn{6}{|c|}{2019 yılı } \\
\hline Aladağ & 4757 & 40257.7 & 6425.1 & 1434.7 & 1.82 & 1.02 & 2.66 \\
\hline Ceyhan & 26653 & 259815.0 & 39894.9 & 5729.9 & 11.77 & 6.34 & 10.64 \\
\hline Feke & 24749 & 257209.7 & 42255.3 & 3954.8 & 11.65 & 6.71 & 7.34 \\
\hline Karaisalı & 17472 & 152476.9 & 22302.6 & 5114.4 & 6.91 & 3.54 & 9.49 \\
\hline Karataş & 14327 & 134459.1 & 31151.7 & 2549.9 & 6.09 & 4.95 & 4.73 \\
\hline Kozan & 25079 & 239144.7 & 20460.8 & 7159.2 & 10.83 & 3.25 & 13.29 \\
\hline Pozant1 & 1912 & 18221.9 & 2318.1 & 481.6 & 0.83 & 0.37 & 0.89 \\
\hline Saimbeyli & 8588 & 85192.5 & 5811.2 & 2363.5 & 3.86 & 0.92 & 4.39 \\
\hline Sarıçam & 30090 & 313068.2 & 28473.7 & 6746.5 & 14.18 & 4.52 & 12.52 \\
\hline Seyhan & 42106 & 145586.8 & 316375.1 & 2662.2 & 6.59 & 50.24 & 4.94 \\
\hline Tufanbeyli & 14918 & 136373.9 & 16861.9 & 4196.5 & 6.18 & 2.68 & 7.79 \\
\hline Yumurtalık & 7236 & 75273.2 & 5768.8 & 1715.4 & 3.41 & 0.92 & 3.18 \\
\hline Yüreğir & 27164 & 212651.6 & 79154.6 & 5555.2 & 9.63 & 12.57 & 10.31 \\
\hline Çukurova & 4650 & 42376.5 & 5504.2 & 1294.4 & 1.92 & 0.87 & 2.40 \\
\hline İmamoğlu & 9983 & 95880.8 & 6933.2 & 2913.8 & 4.34 & 1.10 & 5.41 \\
\hline Toplam & 259684 & 2207988.3 & 629691.1 & 53872.1 & 100.00 & 100.00 & 100.00 \\
\hline
\end{tabular}


Çizelge 4. Kümes hayvanları için gübre üretim miktarları

Table 4. Manure production amounts for poultry

\begin{tabular}{|c|c|c|c|c|c|}
\hline \multirow{3}{*}{ İlçe } & \multirow[b]{2}{*}{ Toplam Hayvan } & \multicolumn{2}{|c|}{ Yıllık Gübre Üretimi (ton yıl ${ }^{-1}$ ) } & \multicolumn{2}{|c|}{ İlçelere Göre Dağılım Oranları (\%) } \\
\hline & & Et Tavuğu & Yumurta Tavuğu & Et Tavuğu & Yumurta Tavuğu \\
\hline & & \multicolumn{4}{|c|}{2018 yılı } \\
\hline Aladağ & 298000 & 20458.3 & 142.4 & 4.7 & 0.3 \\
\hline Ceyhan & 1562000 & 86687.5 & 14804.4 & 19.8 & 33.9 \\
\hline Feke & 17830 & 0.0 & 846.0 & 0.0 & 1.9 \\
\hline Karaisalı & 505877 & 34581.4 & 342.9 & 7.9 & 0.8 \\
\hline Karataş & 5325 & 0.0 & 252.7 & 0.0 & 0.6 \\
\hline Kozan & 85000 & 3120.8 & 1898.0 & 0.7 & 4.3 \\
\hline Pozant1 & 66690 & 4507.8 & 80.2 & 1.0 & 0.2 \\
\hline Saimbeyli & 17200 & 0.0 & 816.1 & 0.0 & 1.9 \\
\hline Sarıçam & 991000 & 52775.4 & 10913.5 & 12.0 & 25.0 \\
\hline Seyhan & 1736830 & 108511.3 & 8168.0 & 24.8 & 18.7 \\
\hline Tufanbeyli & 14500 & 0.0 & 688.0 & 0.0 & 1.6 \\
\hline Yumurtalık & 15000 & 0.0 & 711.8 & 0.0 & 1.6 \\
\hline Yüreğir & 1378650 & 95356.3 & 173.2 & 21.8 & 0.4 \\
\hline Çukurova & 322500 & 22192.0 & 118.6 & 5.1 & 0.3 \\
\hline İmamoğlu & 219846 & 9793.2 & 3731.1 & 2.2 & 8.5 \\
\hline Toplam & 7236248 & 437983.7 & 43.686 .9 & 100.0 & 100.0 \\
\hline \multirow{3}{*}{ İlçe } & & \multicolumn{2}{|c|}{ Yıllık Gübre Üretimi (ton yıl $\left.{ }^{-1}\right)$} & \multicolumn{2}{|c|}{ İlçelere Göre Dağılım Oranları (\%) } \\
\hline & Toplam Hayvan & Et Tavuğu & Yumurta Tavuğu & Et Tavuğu & Yumurta Tavuğu \\
\hline & & \multicolumn{4}{|c|}{2019 yılı } \\
\hline Aladağ & 295000 & 20458.3 & 0.0 & 4.9 & 0.0 \\
\hline Ceyhan & 1224971 & 82486.3 & 1686.8 & 19.8 & 6.5 \\
\hline Feke & 17840 & 0.0 & 846.5 & 0.0 & 3.2 \\
\hline Karaisalı & 512999 & 35004.3 & 391.5 & 8.4 & 1.5 \\
\hline Karataş & 4325 & 0.0 & 205.2 & 0.0 & 0.8 \\
\hline Kozan & 83000 & 3120.8 & 1803.1 & 0.7 & 6.9 \\
\hline Pozantı & 65600 & 4507.8 & 28.5 & 1.1 & 0.1 \\
\hline Saimbeyli & 16900 & 0.0 & 801.9 & 0.0 & 3.1 \\
\hline Sarıçam & 765000 & 44730.8 & 5694.0 & 10.7 & 21.8 \\
\hline Seyhan & 1766885 & 108513.0 & 9593.0 & 26.1 & 36.7 \\
\hline Tufanbeyli & 14650 & 0.0 & 695.1 & 0.0 & 2.7 \\
\hline Yumurtalık & 14950 & 0.0 & 709.4 & 0.0 & 2.7 \\
\hline Yüreğir & 1255350 & 86774.2 & 194.5 & 20.8 & 0.7 \\
\hline Çukurova & 322750 & 22192.0 & 130.5 & 5.3 & 0.5 \\
\hline İmamoğlu & 196400 & 8738.1 & 3340.5 & 2.1 & 12.8 \\
\hline Toplam & 6556620 & 416525.5 & 26120.5 & 100.0 & 100.0 \\
\hline
\end{tabular}

$\mathrm{Bu}$ konuda yapılan çalışmalar, kıyaslama yapabilmek için kapsamlı olarak araştırılmış ve çalışmaların ilgili bulguları özetlenmiştir. Seçilen çalışma alanlarındaki farklı hayvancılık dokuları ve incelenmek üzere ele alınan hayvan türleri ve sayıları değişkenlik gösterdiğinden elde edilen sonuçlar da farklılaşmıştır fakat veriler yöntem bazında incelendiğinde sonuçların paralellik gösterdiği ve çarpıcı miktarlarda olduğu görülmektedir. Adana il merkezi ve ilçelerinde hayvancılık faaliyetleri sonucunda oluşan $\sum \mathrm{N}$ ve $\sum \mathrm{P}$ yükleri yüzeysel akış ile yüzey su kaynaklarına ve doğal çevreye; derine sızma ile de yeraltı sularına taşınmaktadır (Erkan Can 2011). Kontrolsüzce toprak üzerinde bekletilen veya çevreye atılan hayvan gübreleri ve hayvancılık faaliyetlerinden kaynaklanan atıklar çevre ve su kaynakları açısından tehlikeli boyutlara varabilecek yayılı kirletici kaynaklarıdır. Çizelgelerde verilen rakamlardan da görülebileceği gibi $\sum \mathrm{N}$ ve $\sum \mathrm{P}$ yükleri de kirletici olarak yayılım yapacaktır.
Adana ilinin $14030 \mathrm{~km}^{2}$ lik yüzölçümünün \%28'ini ovalar, \%38'ini tarımsal araziler, \%3'ünü meralar oluşturmaktadır. Adana ilinin Akdeniz'e $160 \mathrm{~km}$ uzunluğunda kıyısı vardır. Akdeniz Bölgesi'nin en büyük 1rmakları olan Seyhan (560 km) ve Ceyhan $(509 \mathrm{~km})$ Adana toprakları içinden akmaktadır. Ayrıca ilde, ülke genelindeki önemli barajlar ve baraj gölleri arasında yer alan Seyhan Baraj Gölü, Kozan Barajı ve gölü, Nergizlik Barajı ve gölü, Çatalan Barajı ve gölü; bunun yanı sıra Yumurtalık ve Akyatan (Ağyatan) gibi önemli lagünler ve Karaisalı ilçesi civarında Karstik Dipsiz Göl bulunmaktadır. Bu bilgilerden yola çıkarak; kontrolsüz hayvancılık faaliyetlerinin, gerek üretilen hayvan gübresi miktarları gerekse yeterli gübre yönetim sistemlerinin olmayışı ve ortaya çıkan kirlilik yükü ile sözü edilen ırmak, göl ve diğer su kaynakları ile doğal çevreye ciddi zararlar vereceği aşikârdır. Hayvan gübrelerinden kaynaklanan yayılı $\sum \mathrm{N}$ ve $\sum \mathrm{P}$ yükleri yüzey akış ve sediment 
taşınımı ile yatay doğrultuda ve derine sızma şeklinde de düşey doğrultuda kirlilik tehdidi olacaktır.

Kirlilik yüklerinin Adana merkez ve ilçelerine göre dağılım yüzdeleri Şekil 1'de verilmiştir.

Şekil incelendiğinde büyükbaş, etlik piliç ve yumurta tavuğu kaynaklı hayvansal gübrenin ve kirlilik yükünün 2019'da kısmen de olsa artış gösterdiği ve hayvancılığın yoğun olarak yapıldığı Adana merkez ilçeleri olan Seyhan, Yüreğir ve Sarıçam'da yoğunlaştığı bu sıralamayı da Ceyhan ilçesinin takip ettiği görülmektedir.

\section{Sonuç ve Öneriler}

Kirlilik kaynaklarını noktasal kirletici kaynakları ve yayılı kirletici kaynakları olarak iki farklı başlık altında toplamak mümkündür. Hayvancılık işletmeleri yapıları gereği belirli ve tek kaynağı olmayan yayılı atık üreten, kirlilik boyutunun kesin olarak belirlenemediği ve net olarak ölçülemediği bir sektör olduğundan yayılı kirletici olarak değerlendirilmektedir. Yayılı kirletici kaynakları birim bazında ele alındığında göz ardı edilse bile tüm yayılı kirletici kaynaklarının toplamda oldukça büyük ve zararlı etkileri olacağı görülebilecektir.

Su kaynaklarına ve doğal çevreye, noktasal olmayan kirlilik kaynaklarından gelen $\sum \mathrm{N}$ ve $\sum \mathrm{P}$ yüklerinin öngörülebilmesi için, bölgesel bazda, kullanılan gübreler ve miktarları, hayvan sayıları, hayvansal atık miktarları, orman, tarımsal arazi, kentsel arazi ve çayır mera alan oranları, bölgedeki atık su toplama ve arıtma durumu, katı atık mevcudu ve uzaklaştırma yöntemleri bilinmeli ve periyodik olarak denetlenmelidir. Ancak bu

Çizelge 5. Hayvancılık faaliyetlerinden kaynaklanan $\sum \mathrm{N}$ ve $\sum \mathrm{P}$ kirlilik yükleri (2018)

Table 5. $\sum \mathrm{N}$ and $\sum \mathrm{P}$ pollution loads from livestock activities (2018)

\begin{tabular}{|c|c|c|c|c|c|}
\hline \multirow[t]{2}{*}{2018 YILI } & \multicolumn{2}{|c|}{ Büyükbaş Hayvanlar } & \multicolumn{2}{|c|}{ Etlik Piliç ve Yumurta Tavuğu } & \multirow{2}{*}{$\begin{array}{c}\text { TOPLAM } \sum \text { N YÜKÜ } \\
\left(_{(t o n} \text { yll }^{-1}\right)\end{array}$} \\
\hline & $\sum \mathrm{N}\left(\right.$ (kg hayvan yll $\left.^{-1}\right)$ & Alıcı Ortama Ulaşan $\sum \mathbf{N}$ & $\sum N\left(\right.$ kg hayvan yll $\left.^{-1}\right)$ & Alıcı Ortama Ulaşan $\sum \mathbf{N}$ & \\
\hline Aladağ & 42344.80 & 6351.72 & 17880.00 & 2682.00 & 9.03 \\
\hline Ceyhan & 216972.00 & 32545.80 & 93720.00 & 14058.00 & 46.60 \\
\hline Feke & 156480.60 & 23472.09 & 1069.80 & 160.47 & 23.63 \\
\hline Karaisalı & 141056.40 & 21158.46 & 30352.62 & 4552.89 & 25.71 \\
\hline Karataş & 124148.00 & 18622.20 & 319.50 & 47.93 & 18.67 \\
\hline Kozan & 225057.20 & 33758.58 & 5100.00 & 765.00 & 34.52 \\
\hline Pozant1 & 12373.80 & 1856.07 & 4001.40 & 600.21 & 2.46 \\
\hline Saimbeyli & 53455.80 & 8018.37 & 1032.00 & 154.80 & 8.17 \\
\hline Sarıçam & 395494.20 & 59324.13 & 59460.00 & 8919.00 & 68.24 \\
\hline Seyhan & 273068.20 & 40960.23 & 104209.80 & 15631.47 & 56.59 \\
\hline Tufanbeyli & 115710.20 & 17356.53 & 870.00 & 130.50 & 17.49 \\
\hline Yumurtalık & 68183.00 & 10227.45 & 900.00 & 135.00 & 10.36 \\
\hline Yüreğir & 255348.00 & 38302.20 & 82719.00 & 12407.85 & 50.71 \\
\hline Çukurova & 34989.40 & 5248.41 & 19350.00 & 2902.50 & 8.15 \\
\hline İmamoğlu & 61844.40 & 9276.66 & 13190.76 & 1978.61 & 11.26 \\
\hline Toplam & 2176526.00 & 326478.90 & 434174.88 & 65126.23 & 391.61 \\
\hline \multirow[t]{2}{*}{2018 YILI } & \multicolumn{2}{|c|}{ Büyükbaş Hayvanlar } & \multicolumn{2}{|c|}{ Etlik Piliç ve Yumurta Tavuğu } & TOPLAM $\sum P$ YÜKÜ \\
\hline & $\sum P\left(\right.$ kg hayvan yll $\left.^{-1}\right)$ & Alıcı Ortama Ulaşan $\sum \mathbf{P}$ & $\sum P\left({\left.\text { kg hayvan } \text { yll }^{-1}\right)}\right.$ & Alıcı Ortama Ulaşan $\sum \mathbf{P}$ & $\left(\right.$ ton $\left.\mathrm{yll}^{-1}\right)$ \\
\hline Aladağ & 4699.24 & 234.96 & 2384.00 & 119.20 & 0.35 \\
\hline Ceyhan & 24078.60 & 1203.93 & 12496.00 & 624.80 & 1.83 \\
\hline Feke & 17365.53 & 868.28 & 142.64 & 7.13 & 0.88 \\
\hline Karaisalı & 15653.82 & 782.69 & 4047.02 & 202.35 & 0.99 \\
\hline Karataş & 13777.40 & 688.87 & 42.60 & 2.13 & 0.69 \\
\hline Kozan & 24975.86 & 1248.79 & 680.00 & 34.00 & 1.28 \\
\hline Pozant1 & 1373.19 & 68.66 & 533.52 & 26.68 & 0.10 \\
\hline Saimbeyli & 5932.29 & 296.61 & 137.60 & 6.88 & 0.30 \\
\hline Sarıçam & 43890.21 & 2194.51 & 7928.00 & 396.40 & 2.59 \\
\hline Seyhan & 30303.91 & 1515.20 & 13894.64 & 694.73 & 2.21 \\
\hline Tufanbeyli & 12841.01 & 642.05 & 116.00 & 5.80 & 0.65 \\
\hline Yumurtalık & 7566.65 & 378.33 & 120.00 & 6.00 & 0.38 \\
\hline Yüreğir & 28337.40 & 1416.87 & 11029.20 & 551.46 & 1.97 \\
\hline Çukurova & 3882.97 & 194.15 & 2580.00 & 129.00 & 0.32 \\
\hline İmamoğlu & 6863.22 & 343.16 & 1758.77 & 87.94 & 0.43 \\
\hline Toplam & 241541.30 & 12077.07 & 57889.98 & 2894.50 & 14.97 \\
\hline
\end{tabular}


Çizelge 6. Hayvancılık faaliyetlerinden kaynaklanan $\sum \mathrm{N}$ ve $\sum \mathrm{P}$ kirlilik yükleri (2019)

Table 6. $\Sigma N$ and $\sum P$ pollution loads from livestock activities (2019)

\begin{tabular}{|c|c|c|c|c|c|}
\hline \multirow{2}{*}{2019 YILI } & \multicolumn{2}{|c|}{ Büyükbaș Hayvanlar } & \multicolumn{2}{|c|}{ Etlik Piliç ve Yumurta Tavuğu } & \multirow{2}{*}{ 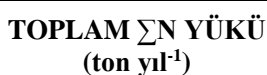 } \\
\hline & $\sum \mathrm{N}\left({\left.\text { (kg hayvan } \text { yll }^{-1}\right)}^{-1}\right.$ & Alıcı Ortama Ulaşan $\sum N$ & $\sum \mathrm{N}\left(\right.$ (kg hayvan $\left.\mathrm{yll}^{-1}\right)$ & Alıcı Ortama Ulaşan $\sum \mathbf{N}$ & \\
\hline Aladağ & 39007.40 & 5851.11 & 285.42 & 42.81 & 5.89 \\
\hline Ceyhan & 218554.60 & 32783.19 & 1599.18 & 239.88 & 33.02 \\
\hline Feke & 202941.80 & 30441.27 & 1484.94 & 222.74 & 30.66 \\
\hline Karaisalı & 143270.40 & 21490.56 & 1048.32 & 157.25 & 21.65 \\
\hline Karataş & 117481.40 & 17622.21 & 859.62 & 128.94 & 17.75 \\
\hline Kozan & 205647.80 & 30847.17 & 1504.74 & 225.71 & 31.07 \\
\hline Pozant1 & 15678.40 & 2351.76 & 114.72 & 17.21 & 2.37 \\
\hline Saimbeyli & 70421.60 & 10563.24 & 515.28 & 77.29 & 10.64 \\
\hline Sarıçam & 246738.00 & 37010.70 & 1805.40 & 270.81 & 37.28 \\
\hline Seyhan & 345269.20 & 51790.38 & 2526.36 & 378.95 & 52.17 \\
\hline Tufanbeyli & 122327.60 & 18349.14 & 895.08 & 134.26 & 18.48 \\
\hline Yumurtalık & 59335.20 & 8900.28 & 434.16 & 65.12 & 8.97 \\
\hline Yüreğir & 222744.80 & 33411.72 & 1629.84 & 244.48 & 33.66 \\
\hline Çukurova & 38130.00 & 5719.50 & 279.00 & 41.85 & 5.76 \\
\hline İmamoğlu & 81860.60 & 12279.09 & 598.98 & 89.85 & 12.37 \\
\hline Toplam & 2129408.80 & 319411.32 & 15581.04 & 2337.16 & 321.75 \\
\hline \multirow{2}{*}{2019 YILI } & \multicolumn{2}{|c|}{ Büyükbaş Hayvanlar } & \multicolumn{2}{|c|}{ Etlik Piliç ve Yumurta Tavuğu } & TOPLAM $\sum P$ YÜKÜ \\
\hline & $\sum P\left(\right.$ kg hayvan yll $\left.^{-1}\right)$ & Alıcı Ortama Ulaşan $\sum \mathbf{P}$ & $\sum P\left(\right.$ kg hayvan yil $\left.^{-1}\right)$ & Alıcı Ortama Ulaşan $\sum \mathbf{P}$ & $\left(\right.$ ton yll $\left.^{-1}\right)$ \\
\hline Aladağ & 4328.87 & 216.44 & 2360.00 & 118.00 & 0.33 \\
\hline Ceyhan & 24254.23 & 1212.71 & 9799.77 & 489.99 & 1.70 \\
\hline Feke & 22521.59 & 1126.08 & 142.72 & 7.14 & 1.13 \\
\hline Karaisalı & 15899.52 & 794.98 & 4103.99 & 205.20 & 1.00 \\
\hline Karataş & 13037.57 & 651.88 & 34.60 & 1.73 & 0.65 \\
\hline Kozan & 22821.89 & 1141.09 & 664.00 & 33.20 & 1.17 \\
\hline Pozant1 & 1739.92 & 87.00 & 524.80 & 26.24 & 0.11 \\
\hline Saimbeyli & 7815.08 & 390.75 & 135.20 & 6.76 & 0.40 \\
\hline Sarıçam & 27381.90 & 1369.10 & 6120.00 & 306.00 & 1.68 \\
\hline Seyhan & 38316.46 & 1915.82 & 14135.08 & 706.75 & 2.62 \\
\hline Tufanbeyli & 13575.38 & 678.77 & 117.20 & 5.86 & 0.68 \\
\hline Yumurtalık & 6584.76 & 329.24 & 119.60 & 5.98 & 0.34 \\
\hline Yüreğir & 24719.24 & 1235.96 & 10042.80 & 502.14 & 1.74 \\
\hline Çukurova & 4231.50 & 211.58 & 2582.00 & 129.10 & 0.34 \\
\hline İmamoğlu & 9084.53 & 454.23 & 1571.20 & 78.56 & 0.53 \\
\hline Toplam & 236312.44 & 11815.62 & 52452.96 & 2622.65 & 14.44 \\
\hline
\end{tabular}

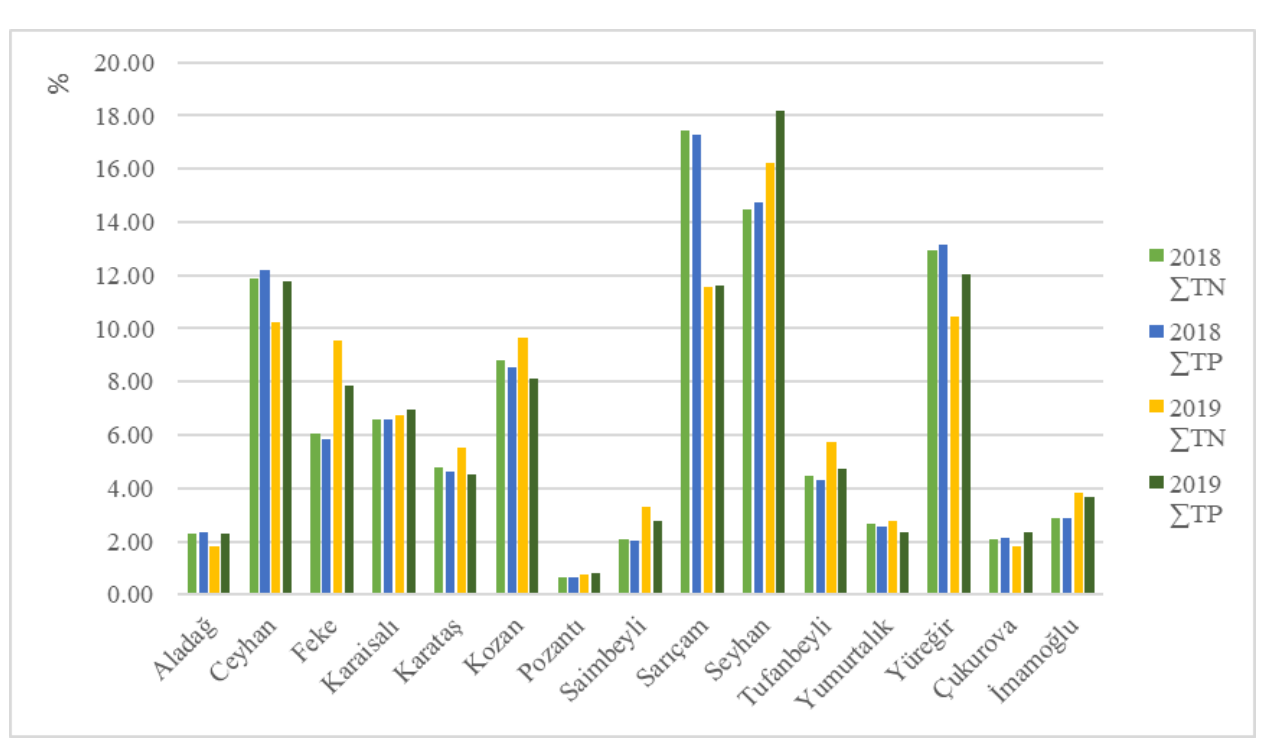

Şekil 1. Hayvancılık kaynaklı kirlilik yükü dağılımı (\%).

Figure 1. Distribution of pollution load from livestock (\%). 
bilgilerin bir kısmına ulaşmak çoğu zaman mümkün olmamaktadır. Türkiye için bilgiler, çeşitli veri tabanlarında standart bir formatta olmayı ilçe veya il düzeyinde bulunabilmektedir. Böyle bir durumda uygun istatistiksel yöntemler ile eksik verilerin tahmin edilmesi veya konu üzerinde yapılan çalışmalarla veri üretilerek mevcut durumun güncellenmesi ve aydınlatılması gerekmektedir. Bunun yanı sıra, yayılı kirletici kaynaklı $\sum \mathrm{N}$ ve $\sum \mathrm{P}$ yükleri belirlenirken karşılaşılan diğer bir önemli sorun ise veri tabanları arasındaki uyuşmazlıklardır. $\mathrm{Bu}$ sorun da yine ilgili alanda yürütülen araştırmaların ve bahsedilen bilgilerin temini için yapılan kapsamlı saha çalışmalarının önemine dikkat çekmektedir.

Söz konusu hayvancılık verilerinin titizlikle derlenerek sınıflandırılmasına ve amaca uygun olarak işlenmesine yönelik bu çalışma sonuçları, hem Adana ili ve ilçeleri için hem de benzer hayvan sayısına, iklime ve topoğrafyaya sahip olan yöreler için, ortaya çıkan yüksek miktarlardaki hayvan gübresi potansiyeline ve yarattı̆̆ 1 kirlilik risklerine dikkat çekmektedir. Büyük miktarlardaki hayvan gübresi, tehlikeli bir kirletici halini almadan, uygun gübre yönetim ve değerlendirme sistemlerine tabi tutularak çevreye en az zararla, değerli bir bitki besin elementi elde edilmesi için gereken altyapı oluşturulmalı, desteklenmeli ve denetlenmelidir.

\section{Teşekkür}

$\mathrm{Bu}$ çalışma Çukurova Üniversitesi Bilimsel Araştırma Projeleri Koordinasyon Birimi tarafindan FBA-2017-7450 nolu proje ile desteklenmiştir.

\section{Kaynaklar}

Adana Tarım Master Planı (2005) Tarım ve Köyişleri Bakanlığı, Adana Tarım İl Müdürlüğü, Araștırma Planlama ve Koordinasyon Kurulu Başkanlığı, İl Tarım ve Kırsal Kalkınma Master Planlarının Hazırlanmasına Destek Projesi, Adana.

Andreadakis A, Gavalakis E, Kaliakatsos L, Noutsopoulos C, Tzimas A (2007) The implementation of the water framework directive (WFD) at the river basin of Anthemountas with emphasis on the pressures and impacts analysis. Desalination (210): 1-15.

Animal Waste (2001) Wyoming Agricultural Statistics Service Wyoming Agricultural Statistics. www. wyomingbusiness.org/ pdf/energy/biomass3.pdf. Erişim Ocak 2009.

Aybek A, Üçok S, Bilgili ME, İspir MA (2015) Kahramanmaraş ilinde bazı tarımsal atıkların biyogaz enerji potansiyelinin belirlenerek sayısal haritalarının oluşturulması. Uludağ Üniversitesi Ziraat Fakültesi Dergisi 29(2): 25-37.

Ayhan A (2015) Biogas production potential from animal manure of Bursa province. Journal of Agricultural Faculty of Uludağ University 29(2): 47-53.

Biçer CA (2011) Göl alt havzaları bazında yayılı kaynaklardan oluşan N ve P yükünün tahmini: Burdur Havzası örneği. Yüksek Lisans Tezi. İstanbul Teknik Üniversitesi, Fen Bilimleri Enstitüsü, Çevre Bilimleri ve Mühendisliği Anabilim Dalı.

Dağtekin M, Aybek A, Bilgili E (2019) Adana ve Mersin'de bulunan etlik piliç kümeslerinde oluşan gübrenin biyogaz ve elektrik üretim potansiyelinin belirlenmesi. Çukurova Üniversitesi Mühendislik Mimarlık Fakültesi Dergisi 34(2): 9-22.

Derin P, Demir Yetiş A, Yeşilnacar İ, Yetiş R (2019) Mardin merkez ve ilçeleri için anropojenik yayılı kirletici kaynaklarından hayvansal kirlilik yükünün belirlenmesi. Uluslararası Katılımlı 72. Türkiye Jeoloji Kurultay1, Ankara, s. 694-698.
Erkan Can M (2011) Adana ili büyükbaş hayvancılık işletmelerinde elde edilen gübrenin taban suyuna etkileri. Doktora Tezi, Çukurova Üniversitesi Fen Bilimleri Enstitüsü Tarımsal Yapılar ve Sulama Anabilim Dalı.

Kaçar B, Katkat V (2009) Gübreler ve gübreleme tekniği. 3. Baskı. Nobel Yayın Dağıtım Ltd. Yayın no: 1119, s. 17-54.

Kaplan M (1999) Yeni bir kompoze gübre üretim önerisi. Ekin Dergisi 8: 30-31.

Kurnuç Seyhan A, Badem A (2018) Erzincan ilindeki hayvansal atıkların biyogaz potansiyelinin araştırılması. Akademik Platform Mühendislik ve Fen Bilimleri Dergisi 6(1): 25-35.

Kütük C, Çaycı G (2010) Tavuk dışkılarının organik gübreye dönüştürülme yöntemleri. Kümes Hayvanları Kongresi, Kayseri, s. 8.

Olgun M, Polat HE (2005) Ülkemizdeki hayvancılık işletmelerinde atık yönetim sistemlerinin değerlendirilmesi. TMMOB Çevre Mühendisleri Odası, 6. Ulusal Çevre Mühendisliği Kongresi, İstanbul, s. 206-211.

Orman ve Su işleri Bakanlığı (2013) Türkiye’de Havza Bazında Hassas Alanların ve Su Kalitesi Hedeflerinin Belirlenmesi Projesi Nihai Raporu, Cilt 1.

Öztürk İ (2008) Büyük İstanbul içme suyu projesi II. merhale melen sistemi Büyük Melen Havzası entegre koruma ve su yönetimi master planı, Nihai Rapor, İTÜ, İstanbul.

Polat Bulut A, Topal Canbaz G (2019) Hayvan atıklarından Sivas İli biyogaz potansiyelinin araştırılması. Karaelmas Fen ve Mühendislik Dergisi 9(1): 1-10.

Salihoğlu NK, Teksoy A, Altan K (2019) Büyükbaş ve küçükbaş hayvan atıklarından biyogaz üretim potansiyelinin belirlenmesi: Balıkesir ili örneği. Ömer Halisdemir Üniversitesi Mühendislik Bilimleri Dergisi 8(1): 31-47.

Tinmaz Köse E (2017) Trakya bölgesinde hayvan gübrelerinin biyogaz enerji potansiyelinin belirlenmesi ve sayısal haritaların oluşturulması. Pamukkale Üniversitesi Mühendislik Bilimleri Dergisi 23(6): 762-772.

TUIKK (2018) Türkiye İstatistik Kurumu 2018 yılı hayvancılık istatistikleri veri tabanı. http://www.tuik.gov.tr/PreTabloArama.do? metod=search\&araType=vt. Erişim Kasım 2019.

TUİK (2019) Türkiye İstatistik Kurumu 2019 yılı hayvancılık istatistikleri veri tabanı. http://www.tuik.gov.tr/PreTabloArama.do? metod=search\&araType=vt. Erişim Kasım 2019.

Yağlı H, Koç Y (2019) Hayvan gübresinden biyogaz üretim potansiyelinin belirlenmesi: Adana ili örnek hesaplama. Çukurova Üniversitesi Mühendislik Mimarlık Fakültesi Dergisi 34(3): 35-48.

Yelmen B, Dağtekin M, Çakır MT (2020) Mersin ilinin organik atık potansiyelinin biyogaz enerji üretimine etkisi. Politeknik Dergisi 23(2): 587-595.

Yetiş DA, Yetiş R, Gazigil L (2018a) Bitlis Merkez ve ilçelerinin hayvansal kaynaklı kirlilik yükü hesabı. International Symposium on Urban Water and Wastewater Management, Denizli, s. 610-617.

Yetiş DA, Teke RB, Yetiş R (2018b) Muş Merkez ve ilçelerinin hayvansal kaynaklı kirlilik yükü hesabı. 6th International GAP Engineering Conference, Şanliurfa, s. 527-532. 